\title{
Anatomy and cell wall chemistry of tension wood in Hibiscus cannabinus
}

\author{
Anatomía y química de la pared celular de la madera de tensión en Hibiscus cannabinus
}

\author{
Pramod Sivan ${ }^{\text {a, }}$, Karumanchi S Rao ${ }^{\text {b }}$, Kishore S Rajput ${ }^{\text {c* }}$ \\ ${ }^{a}$ Swedish University of Agricultural Sciences, Umea Plant Science Centre, \\ Department of Forest Genetics and Plant Physiology, Umea, Sweden. \\ b Sardar Patel University, Department of Biosciences, Vallabh Vidyanagar, Gujarat, India. \\ *Corresponding author: ${ }^{\mathrm{c}}$ The Maharaja Sayajirao University of Baroda, Faculty of Science, \\ Department of Botany, Tilak Road, Vadodara 390002, India, phone: +91 265 2791891, ks.rajput15@yahoo.com
}

\begin{abstract}
SUMMARY
Hibiscus cannabinus (kenaf) is well known as a source for textile fibers and as an alternate source for cellulosic fibers for paper and pulp industry. Formation of reaction xylem alters the chemical properties of fibers, which may affect its uses. To the best of our knowledge, there are no reports on the occurrence of reaction xylem in kenaf. The present study examines reaction xylem (i.e. tension wood and its opposite side) formed in response to bending of stems in Kenaf by anatomical, histochemical and biochemical methods. The reaction xylem found on the upper side of leaning stems showed an eccentric growth pattern, thin walls, shorter and wider fibers without gelatinous layer, decrease of vessel or ray density as compared to wood formed on opposite sides. Histochemical localization of lignin using Weisner reaction and Maule's test indicated presence of more syringyl units in the fiber wall of tension wood. Gravimetric quantification of cell wall polymers showed relatively more amount of holocellulose and hemicellulose in tension wood (69 and $46 \%$, respectively) compared to those of opposite wood ( 63 and $42 \%$, respectively). There was no significant difference noticed in the klason lignin content between opposite $(17.4 \%)$ and tension wood $(16.7 \%)$. Lignin characterization by the thioacidolysis method revealed that the tension wood lignin in kenaf was composed of more amount of syringyl and p-hydroxyphenyl monomers compared to that of opposite side wood. This analysis also suggests that the tension wood lignin is rich in $\beta$-aryl ether linkages in syringyl units resulting in high $\mathrm{S} / \mathrm{G}$ ratio.
\end{abstract}

Key words: kenaf, reaction xylem, lignin characterization, wood chemistry.

\section{RESUMEN}

Hibiscus cannabinus (kenaf) es utilizada para producción de fibras textiles, papel y pulpa. La formación del xilema de reacción altera las propiedades químicas de las fibras, la cual puede afectar sus usos finales. No existen reportes sobre la aparición del xilema de reacción en kenaf. Por ello, el presente estudio describe el xilema de reacción de kenaf, el cual abarca cambios anatómicos, histoquímicos y bioquímicos como respuesta a la inclinación del tallo. El xilema de reacción en el lado superior del tallo inclinado mostró un patrón de crecimiento excéntrico, paredes delgadas, fibras más cortas y menor diámetro, y sin la presencia de una capa gelatinosa característica de la madera de reacción, menor frecuencia de vasos y rayos en comparación con el xilema formado en el lado opuesto. La localización de la lignina por histoquímetría (método de Weisner y prueba de Maule) indicó una mayor cantidad de grupos siringilo en la pared celular del xilema de tensión. La cuantificación gravimétrica de los polímeros en la pared celular mostró mayor porporción de holocelulosa y hemicelulosa en el xilema de tensión, pero no hubo diferencia significativa en el contenido de lignina klason entre el xilema de tensión y el xilema opuesto. El método de tioacidólisis mostró que la lignina en el xilema de tensión estaba compuesta por mayor cantidad de grupos de siringilo y p-hidroxifenilo en relación con la madera opuesta. Estos resultados sugieren que la lignina en el xilema de tensión del kenaf presenta mayor proporción de enlaces de éter $\beta$-arílico en unidades de siringilo, resultando una alta relación $\mathrm{S} / \mathrm{G}$.

Palabras clave: kenaf, madera de reacción, caracterización de lignina, química de la madera.

\section{INTRODUCTION}

Formation of reaction xylem is a dynamic characteristic in the developmental biology of higher plants. In woody angiosperms, reaction xylem is called as tension wood, which is formed as eccentric growth on the upper side of the leaning stems or branches. When the orientation of the main stem is shifted from vertical, formation of tension wood provides the required mechanical reinforcement for optimal architecture of the dicotyledons species in the space (Almeras and Clair 2016, Groover 2016). The physiology of maintaining stems and branches with secondary 
growth in appropriate positions by allowing them to bend through generating tensional longitudinal stress is also attributed to tension wood formation (Clair et al. 2013). In general, tension wood is characterized by the occurrence of gelatinous $(\mathrm{G})$ fiber in which the inner lignified secondary wall layer is replaced by a crystalline cellulosic $G$ layer. Due to the high proportion of G-fibers, tension wood has less lignin content while, high cellulose quantity in the cell wall chemical composition (Baba et al. 1996). On the other hand, there are also reports on the occurrence of reaction xylem, without G-fibers on the side of eccentric growth (Yoshida et al. 2000).

Because of the variation in tissue composition, cell wall structure and chemical composition, tension wood is considered to be important in understanding the relation between physical and physiological stress on plant growth pattern, especially structure and function of cell wall of plants. Plant fibers are the most important raw materials for versatile usage, especially in pulp and paper industry. Therefore, structure and chemical composition of cell wall polymers play a significant role in their commercial use (Ramage et al. 2017). It is therefore necessary to understand the distribution pattern of cell wall polysaccharides and monomeric composition of lignin in plant fibres having commercial importance.

The current understanding on the chemistry of reaction xylem is mainly based on the xylem with gelatinous fibers on the upper side of the bending stem associated with eccentric growth. However, the information available on the cell wall chemistry of reaction xylem showing eccentric growth without gelatinous fibers is meagre. Hibiscus cannabinus L. (kenaf) belongs to Malvaceae, and is well known as a source for textile fibers and as an alternate source for cellulosic fibers for paper and pulp industry (Neto et al. 1996). Hibiscus cannabinus fibers are also suggested to be applied for cellulose derivatives (Saikia et al. 1993), particle boards (Seller et al. 1993) and feedstock for energy and chemicals (Cunninghan et al. 1986). Due to the immense importance of $H$. cannabinus fibers, the structure and chemistry of cell walls have been studied extensively (Jin et al. 2012). The functional properties of reaction xylem have been mainly attributed to the cell wall chemistry variation associated with gelatinous layers (Groover 2016, Pramod et al. 2019). Plausibly, the lignified part of the cell wall may also play a role in functional mechanics of reaction xylem. The major limitation for quantification of chemical variation in lignified walls of typical reaction or tension wood fibers is due to the presence of a thick Glayer. In the present study, we noticed an eccentric growth pattern in the stem of H. cannabinus. Anatomical studies revealed the absence of gelatinous fibers in the eccentric growth side suggesting this reaction xylem is an ideal system for evaluating the structure and chemistry of reaction xylem without G-layers. Therefore, the main aim of the study is to describe the anatomy, distribution pattern of lignin, chemical composition and characterization of lignin monomers in the tension and opposite wood of $H$. cannabinus. To the best of our knowledge, there are no reports on the occurrence of reaction xylem in $H$. cannabinus and our results suggest the dynamic change in lignin chemistry could play a key role in reaction xylem mechanics during upright growth of stems without gelatinous fibers.

\section{METHODS}

Plant material. Samples from bending stems (main) were collected from two-year-old $H$. cannabinus plants growing in the premises of Department of Biosciences, Sardar Patel University, Gujarat, India. Tension wood and opposite wood samples were selected from the area of eccentric growth on the upper side and less growth on lower side respectively. For microscopy, samples were fixed in $2 \%$ glutaraldehyde in phosphate buffer ( $\mathrm{pH}$ 7.2). For biochemical studies, wood pieces were frozen in liquid nitrogen for 1 hour and subsequently dried for 72 hours at $-80{ }^{\circ} \mathrm{C}$. Cell-wall residue (CWR) was obtained by pulverizing the samples in a Wiley mill to pass through an $80 \mu \mathrm{m}$ sieve. The powdered wood (CWR) was afterwards sequentially extracted with distilled water, ethyl alcohol, alcohol: toluene (1:1) and acetone (Merck, Germany) in Soxhlet extractor and dried to get Extractive free xylem residue (EXR). The analysis was conducted in triplicate.

Light microscopy. Transverse, tangential and radial longitudinal sections (15-20 $\mu \mathrm{m}$ thick) were taken from the upper side of the bending stem and its opposite side wood sample using sliding microtome (Leica SM2010R, Germany). Sections were stained with safranin-astra blue (Srebotnik and Messener 1994), dehydrated in ethanolxylene series and embedded in DPX. Lignin was localized in the xylem elements using Wiesner reaction by pouring few drops of $1 \%$ phloroglucinol in ethanol solution on the section mounted on a glass slide followed by adding a drop of $10 \% \mathrm{HCl}$ and covering the sections with cover slip (Vallet et al. 1996). Maule's reaction (Meshitsuka and Nakano 1979) was used to localize the abundance of syringyl lignin moieties in the cell wall. Sections were immersed in $1 \% \mathrm{KMnO}_{4}$ for 5 minutes, washed in distilled water, immersed in $3 \% \mathrm{HCl}$ for 1 minute, washed in distilled water, added few drops of ammonium hydroxide solution and covered with a glass slide. Observations and photography of stained sections were carried out using Leica SM2000 microscope attached with digital camera (Leica DMC2900, Germany).

For measuring the dimension details of xylem elements, small pieces of xylem were macerated by incubating them in Jeffrey's fluid (Berlyn and Miksche 1976) 36-48 hrs. After thorough washing in water, the macerated xylem elements were stained with $0.5 \%$ safranin O (Sigma, USA) before being mounted in $50 \%$ glycerol. The length and width of fibers and vessel elements were measured with an ocular micrometer scale mounted in a research microsco- 
pe. Ray dimension and density $/ \mathrm{mm}^{2}$ area were measured from tangential longitudinal sections using ocular micrometer. Wall thickness of fibers and vessels, and vessel density were measured from transverse sections. For each parameter, 30 measurements were taken randomly for each cell types and statistically analyzed to determine the mean values. Student t-test was carried out to determine statistically significant differences of anatomical parameters at a 0.05 confidence level using Sigmastat software (Version 3.5, San Jose, CA, USA).

FTIR Spectroscopy. Cell wall residues (CWR) and Klason lignin (KL) were used for an FTIR analysis. $\mathrm{KBr}$ pellets for IR spectroscopy were prepared using macro-technique (13 mm ø pellet; Ca. $1.5 \mathrm{mg}$ sample with $350 \mathrm{mg} \mathrm{KBr}$ ). Spectra were recorded with the FTIR spectrometer with TGS detector (Perkin Elmer, Spectrum GS, USA) at resolution of $4 \mathrm{~cm}^{-1}$ for 32 scans in the range from 600 to 4000 $\mathrm{cm}^{-1}$. Background spectra of clear window was recorded prior to acquisition of the sample spectra. The spectrum of the background was subtracted from the spectra of the sample before conversion into absorbance units. For each sample, three different sub samples were analyzed and averaged to give mean spectrum per individual sample.

Determination of holocellulose and $\alpha$-cellulose. The holocellulose and $\alpha$-cellulose was determined using a microanalytical method developed by Yokoyama et al. (2002), $200 \mathrm{mg}$ of EXR were weighed into a $15 \mathrm{ml}$ round bottom flask and placed in water bath at $90{ }^{\circ} \mathrm{C}$. The reaction was initiated by the addition of $1 \mathrm{ml}$ of reaction mixture $(400$ $\mathrm{mg}$ of $80 \%$ Sodium chlorite $+4 \mathrm{ml}$ distilled water +0.4 $\mathrm{ml}$ acetic acid). An additional $1 \mathrm{ml}$ reaction mixture was added every $30 \mathrm{~min}$. The samples were removed to cold water bath after $2 \mathrm{~h}$. The sample was then filtered through a course sintered glass filter (Whatmann, GD 1UM), washed with deionized water $(3 \times 50 \mathrm{ml})$, dried in oven at 105 ${ }^{\circ} \mathrm{C}$ and holocellulose content was determined gravimetrically. For determination of $\alpha$-cellulose, $50 \mathrm{mg}$ of dried holocellulose samples were weighed into reaction flask and allowed to equilibrate for $30 \mathrm{~min}$, subsequently $4 \mathrm{ml}$ of $17.5 \%$ sodium hydroxide were added and allowed to react for $30 \mathrm{~min}$ and next $4 \mathrm{ml}$ of distilled water were added. The sample was macerated for $1 \mathrm{~min}$, allowed to react for $29 \mathrm{~min}$ and after filtered through a sintered glass filter. Following a 5 min soaking in $1.0 \mathrm{M}$ acetic acid, the sample was washed with $90 \mathrm{ml}$ of distilled water $(3 \times 30 \mathrm{ml})$ and dried overnight. The $\alpha$-cellulose was determined gravimetrically.

Determination of lignin content. A lignin analysis was carried out on dry extract free cell wall residue and ground to pass through a 180 micron sieve before exhaustive solvent extraction $\left(2: \mathrm{L}^{1}(\mathrm{v} / \mathrm{v})\right.$ toluene: ethanol, ethanol and water). The lignin content in juvenile and mature wood was determined by Klason lignin method (Dence 1992).
Thioacidolysis. Thioacidolysis was carried out according to Lapierre et al. (1995). The reagent was prepared by introducing $2.5 \mathrm{ml}$ of BF3 etherate (Aldrich) and $10 \mathrm{ml}$ of ethanethiol EtSh (Aldrich) into a $100 \mathrm{ml}$ flask and adjusting the final volume to $100 \mathrm{ml}$ with dioxane. A mixture of the sample $(12 \mathrm{mg})$ and $12 \mathrm{ml}$ of reagent were put in tube fitted with Teflon lined screw cap. Thioacidolysis was performed at $100{ }^{\circ} \mathrm{C}$ (Oil bath) for 4 hours with occasional shaking. The cooled reaction mixture, followed by washings with water, was combined with and the mixture was poured over $1 \mathrm{ml}$ Dichloromethane (Fluka, Germany) including internal standard $(0.50 \mathrm{mg}$ tetracosane from Sigma, Germany). After adjusting the $\mathrm{pH}$ of the aqueous phase to $\mathrm{pH}$ 3-4 with $0.4 \mathrm{M}$ sodium carbonate aqueous solution, the aqueous phase was extracted with dichloromethane $(20 \mathrm{ml} \times 3)$. The combined organic extracts were dried over $\mathrm{Na}_{2} \mathrm{SO}_{4}$ and the solvent was evaporated under reduced pressure at $40{ }^{\circ} \mathrm{C}$ in a rotary evaporator. The residue was re-dissolved in dichloromethane $(1 \mathrm{ml})$. The thioacidolysis products $(7 \mu \mathrm{l})$ were sylated with $50 \mu \mathrm{l}$ of $\mathrm{N}$, O-bis (trimethylsilyl) trifluoroacetamide (BSTFA, Sigma, Germany) and $5 \mu 1$ of pyridine (Sigma, Germany) in a 200 $\mu \mathrm{GC}$ vial with Teflon lined screw cap and kept at room temperature for overnight. The sylated products were separated by Gas chromatography using silicon based capillary column $(30 \mathrm{~m} \times 0.25 \mu \mathrm{m} \times 250 \mu \mathrm{m})$ and each peak was identified by $\mathrm{GC} / \mathrm{MS}$. The temperature program of the $\mathrm{GC}$ increased at a rate of $5{ }^{\circ} \mathrm{C} / \mathrm{min}$ from $100{ }^{\circ} \mathrm{C} / 280{ }^{\circ} \mathrm{C}$ and final temperature was maintained for 60 minutes.

\section{RESULTS}

Anatomical characteristics tension and opposite wood. The secondary xylem of $H$. cannabinus was composed of fibers, vessels (as solitary and radial multiples), paratracheal parenchyma and ray parenchyma cells (figure 1A). Vessels and fibers were characterized by the presence of thick, lignified secondary walls (figure 1A, B). Although axial and ray parenchyma showed lignified cell walls, the thickness of their secondary wall was relatively thin as compared to that of vessel and fibers (figure 1B). Rays were tri-to multiseriate and heterocellular (figure 1C). In terms of tissue composition, tension wood was similar to opposite wood except the ratio of fibers to vessels was found to be higher in tension wood. The thickness of the secondary wall decreased significantly in fibers. On the other hand, the gelatinous layer, a typical characteristics of tension wood was found absent in the fibers in the reaction xylem of $H$. cannabinus (figure 1D). Fibers were identical to axial parenchyma due to similar wall thickness, while distinct by the absence of intercellular spaces and narrow tip compared to parenchyma cells (figure 1D). Ray parenchyma in tension wood appeared to be wider than those of opposite wood (figure 1E).

Measurements from the macerated xylem tissue revealed the dimensional difference of various elements in 


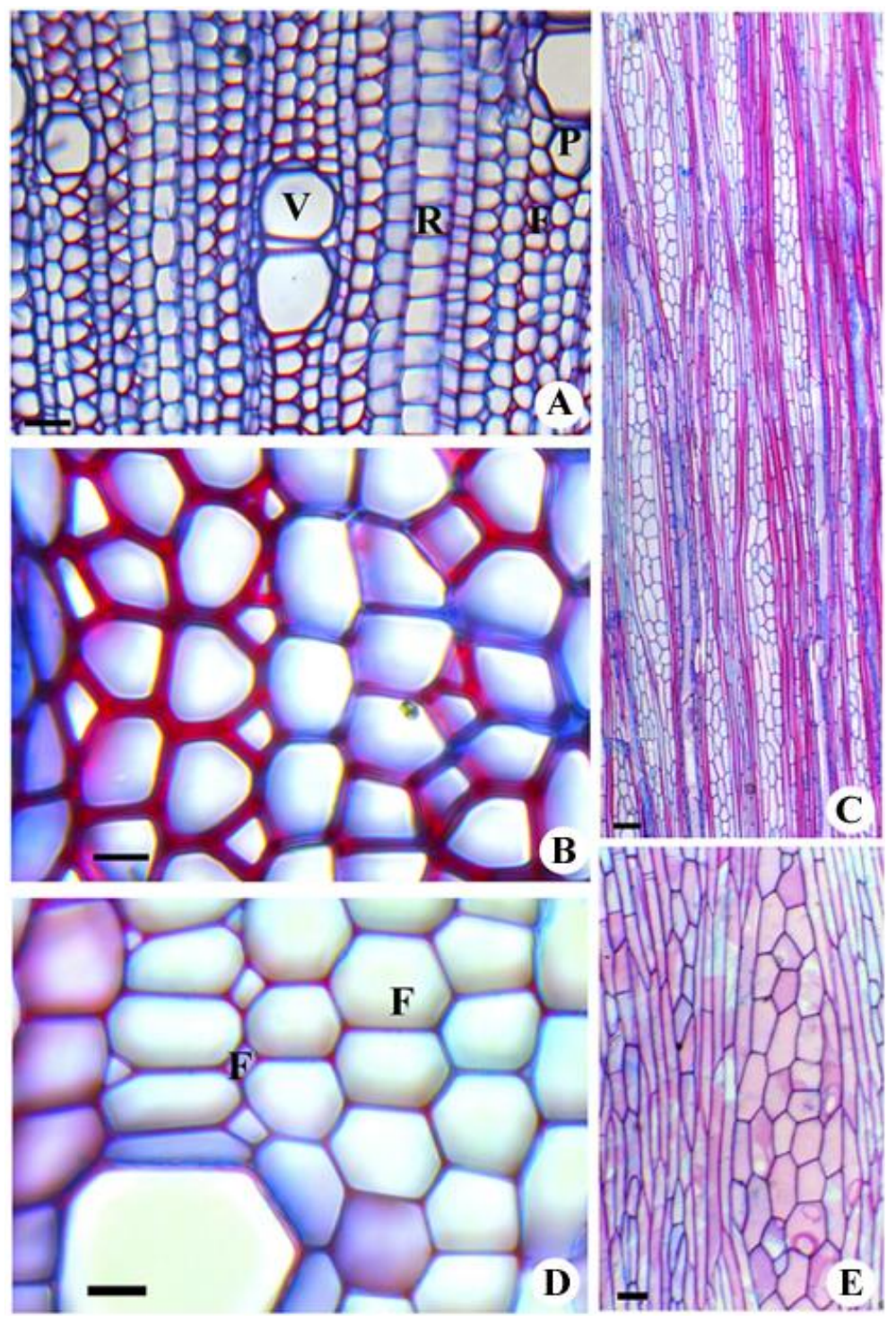

Figure 1 (A-E). Transverse (A, B, D) and tangential longitudinal (C, E) sections of normal wood (A-C) and tension wood (D-E) of $H$. cannabinus.

Cortes microtómicos de secciones transversales (A, B, D) y tangenciales de madera normal (A-C) y madera en tensión (D-E) de $H$. cannabinus.

the tension and opposite wood of H. cannabinus. Tension wood showed a significant decrease in fiber length, wall thickness of fibers and vessel elements, height of rays and density of vessels and rays per unit area as compared to those of opposite wood (table 1). On the other hand, a significant increase in width of fibers and rays was evident in tension wood (table 1). Dimensions of vessel elements did not show any significant variation between tension and opposite wood.

Histochemical localization of lignin in tension wood and opposite wood. Weisner reaction revealed variation of lignification patterns in different xylem elements of opposite and tension wood elements. Opposite wood showed presence of lignin in all xylem elements (figure 2A). Staining intensity was more in the vessel wall suggesting higher lignin concentration compared to other elements (figure 2B). Maules reaction revealed a negative staining reaction from vessel walls, which indicates the presence of more condensed guaiacyl lignin units (figure 2C). Fiber walls showed positive staining reaction due to the presence of more syringyl lignin units (figure 2D). Weisner reaction of tension wood samples showed similar lignin distribution as compared to opposite wood elements (figure 2E). Cell walls of fibers, on the other hand, showed a relatively stronger positive staining reaction to Maule's test indicating the 
Table 1. Anatomical characteristics of normal wood and tension wood of H. cannabinus.

Características anatómicas de la madera de tensión y la madera normal de $H$. cannabinus.

\begin{tabular}{llccc}
\hline Variable & & Normal wood & Tension wood & P-value \\
\hline Fiber & Length & $1093 \pm 234$ & $897 \pm 165$ & $* 0.001$ \\
& Width & $35 \pm 4$ & $44 \pm 3$ & $*<0.001$ \\
& Wall thickness & $3.6 \pm 0.5$ & $1.46 \pm 0.3$ & $*<0.001$ \\
Vessel element & & & \\
& Length & $559 \pm 52$ & $527 \pm 60$ & n.s. 0.398 \\
& Width & $97 \pm 32$ & $100 \pm 17$ & $*<0.001$ \\
& Wall thickness & $4.6 \pm 0.7$ & $3.25 \pm 0.4$ & $*<0.001$ \\
Ray & Vessel density & $15 \pm 2$ & $10 \pm 2$ & $*<0.001$ \\
& & & & $*<0.001$ \\
& Height & $4016 \pm 102$ & $2747 \pm 95$ & $*<0.001$ \\
\end{tabular}

*Significant difference following student t-test $(\alpha=0.05)$, n.s.; non-significant difference, measurements are in $\mu \mathrm{m}$

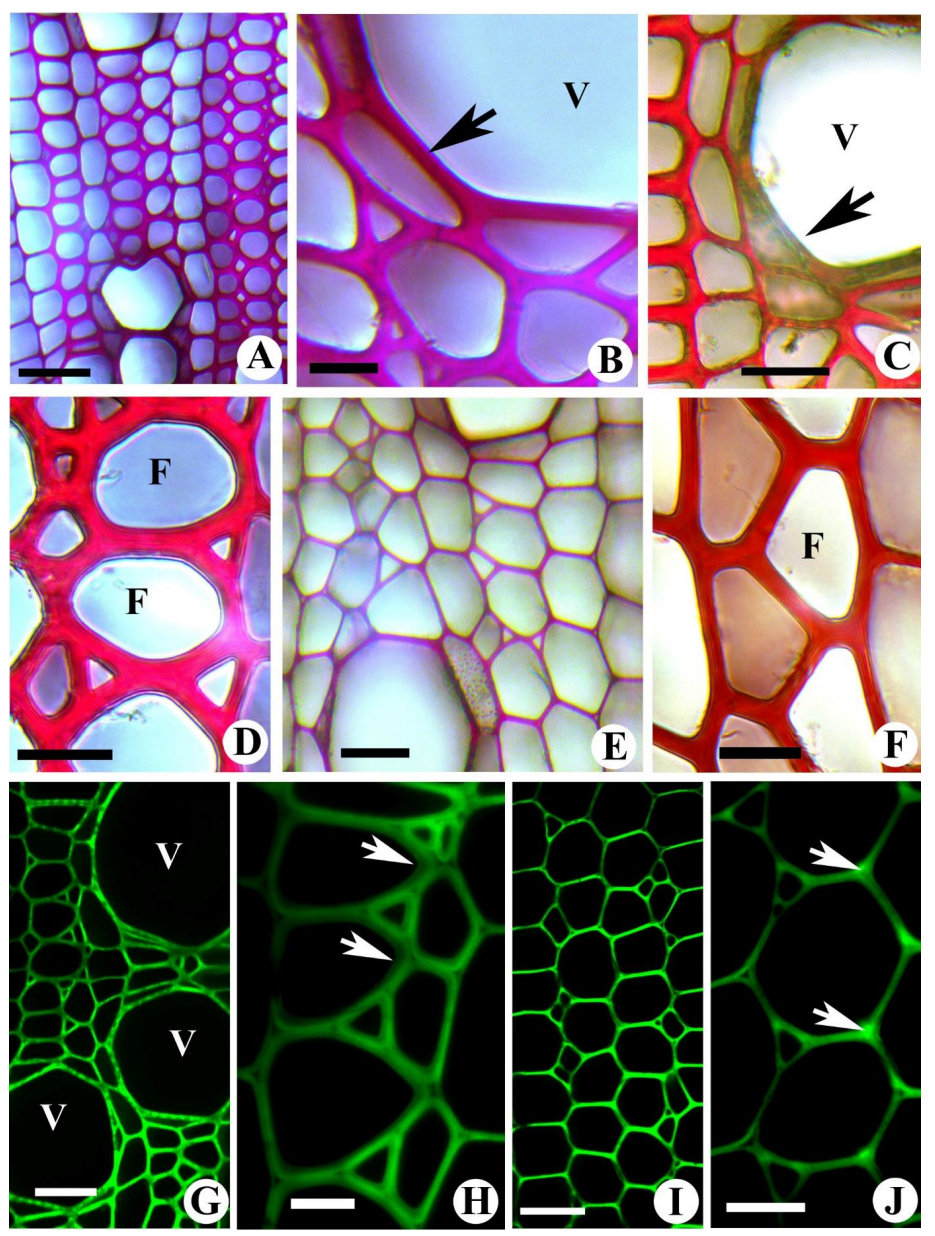

Figure 2 (A-J). Light (A-F) and epi-fluorescence (G-J) images from the transverse section of normal wood (A-D) and tension wood (E-J) of H. cannabinus.

Imágenes al microscopio de luz (A-F) y epi-fluorescencia (G-J) de cortes transversales de la madera normal (A-D) y madera en tensión (E-J) de H. cannabinus. 
presence of more syringyl lignin units (figure 2F). Epifluorescence microscopy of opposite wood xylem showed high intensity of fluorescence from the vessel walls while a weak signal from the secondary wall fibers suggesting the presence of highly condensed lignin units in the former (figure $2 \mathrm{G}, \mathrm{H}$ ). Tension wood also showed a similar pattern of fluorescence compared to opposite wood elements (figure 2I). The cell corners of tension wood fibers showed relatively high fluorescence intensity indicating presence of condensed lignin units in this region (figure 2J).

Analysis of chemical composition of opposite and tension wood by FTIR and gravimetric methods. The analysis of
FTIR spectra of tension and opposite wood showed prominent peaks in the fingerprint region of $1800-600 \mathrm{~cm}^{-1}$ (figure 3). Peaks were numbered and assigned to functional groups and structures according to published literature (table 2).

Most peaks observed in the cell wall residue (CWR) such as 1, 6, 9, 10 and $11(1738,1376,1160,1112$ and $1053 \mathrm{~cm}^{-1}$ respectively) corresponded to polysaccharides (Cellulose and hemicelluloses). Peaks 2, 3, 4, 7 and 8 $\left(1602,1506,1461,1328,1246 \mathrm{~cm}^{-1}\right.$, respectively) were assigned to aromatic skeletal vibration, $\mathrm{C}=\mathrm{O}$ stretching and $\mathrm{CH} 3$ bending vibration in the lignin. These peaks appeared more prominent in the FTIR spectra of klason lignin

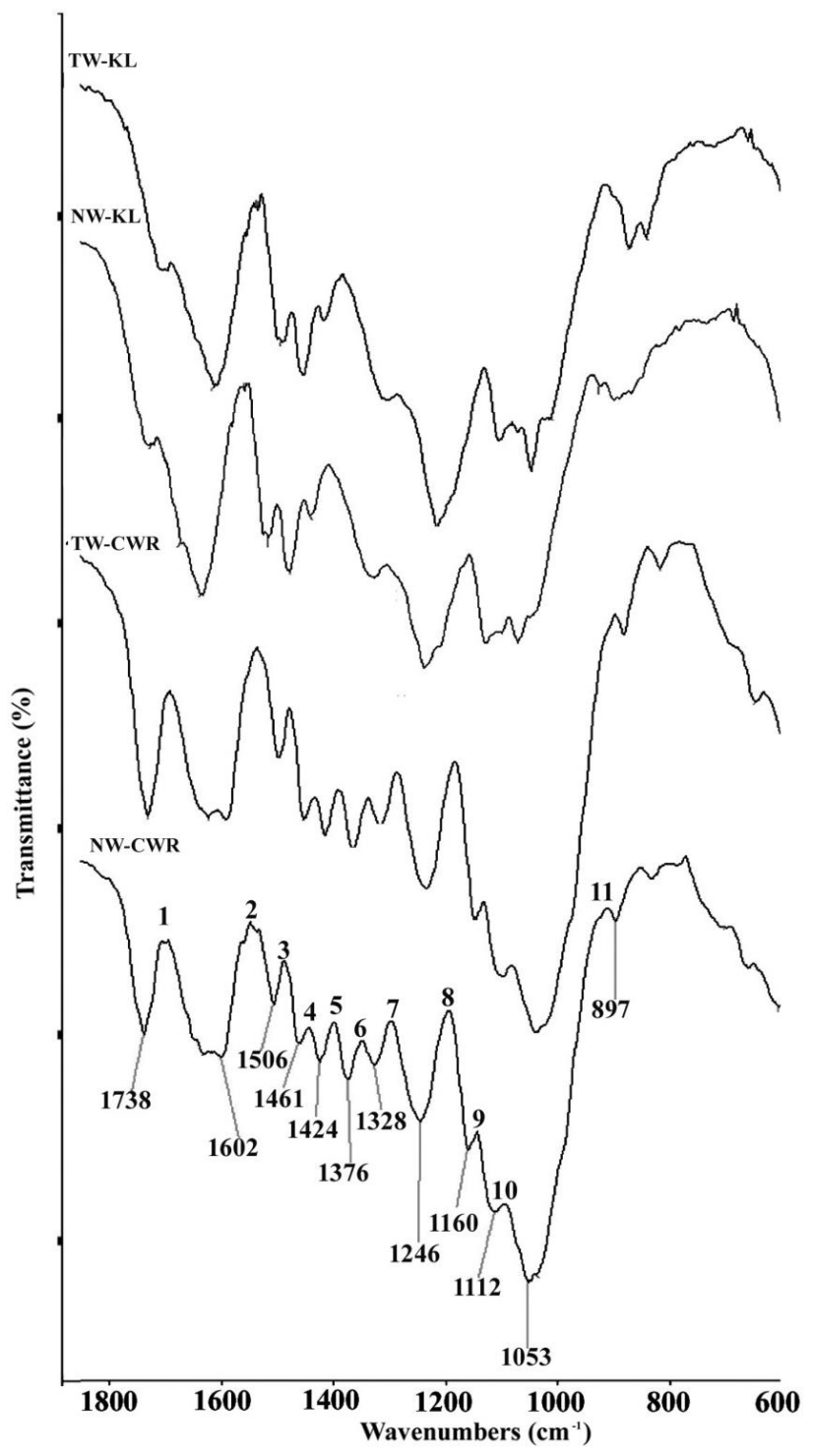

Figure 3. FTIR spectra of cell wall residue (CWR) and Klason lignin (KL) from the normal wood (NW) and tension wood (TW) of H. cannabinus. cannabinus.

Espectros FTIR de residuos de pared celular (CWR) y lignina Klason (KL) de la madera normal (NW) y madera de tensión (TW) de $H$. 
(KL). On the other hand, peaks 1, 6 and 9 of CWR spectra, which correspond to $\mathrm{C}=\mathrm{O}$ stretching, $\mathrm{CH} 3$ bending and $\mathrm{COC}$ anti-symmetric bridge vibration in the cellulose and hemicellulose, did not appear in the KL spectra suggesting their removal during acid hydrolysis. Peaks 2 and 8 , which correspond to benzene ring stretching vibration and $\mathrm{C}=\mathrm{O}$ stretching vibration in lignin, showed a shift in peak position from $1602 \mathrm{~cm}^{-1}$ (CWR) to $1619 \mathrm{~cm}^{-1}(\mathrm{KL})$ and 1246 $\mathrm{cm}^{-1}$ (CWR) to $1223 \mathrm{~cm}^{-1}$ (KL), respectively. The gravimetric quantification of cell wall polysaccharides showed a relatively higher content holocellulose, $\alpha$-cellulose and hemicelluloses in tension wood compared to that of opposite wood (tables 2, 3). There was no significant difference in the lignin content between opposite and tension wood (tables 2, 3).

Characterization of lignin by thioacidolysis method. The results of the gas chromatographic separation of thioacidolytic monomers from opposite and tension wood lignins of $H$. cannabinus are displayed in figure 4.

The monomers of $H$. cannabinus lignin were detected according to Rolando et al. (1992) as both the erythro

Table 2. Chemical composition in normal and tension wood of $H$. cannabinus.

Composición química de la madera de tensión y la madera normal de $H$. cannabinus.

\begin{tabular}{lcc}
\hline Chemical constituent & Normal wood & Tension wood \\
\hline Holocellulose (\%) & $63.23 \pm 0.4$ & $69.50 \pm 0.5$ \\
$\alpha$-cellulose (\%) & $42.61 \pm 1.5$ & $46.45 \pm 0.42$ \\
Hemicellulose (\%) & $20.62 \pm 2.4$ & $23.05 \pm 0.5$ \\
Lignin (\%) & $17.42 \pm 0.3$ & $16.71 \pm 0.5$ \\
\hline
\end{tabular}

Table 3. Band assignments of cell wall residue (CWR) and Klason lignin (KL) from normal and tension wood of H. cannabinus. H. cannabinus.

Asignaciones de bandas para residuos de lignina en pared celular $(\mathrm{CWR}=\mathrm{y}$ lignina Klason para la madera de tensión y la madera normal de

\begin{tabular}{|c|c|c|c|c|c|c|}
\hline \multicolumn{7}{|c|}{ Wave number $\left(\mathrm{cm}^{-1}\right)$} \\
\hline \multirow[t]{2}{*}{ No. } & \multicolumn{2}{|c|}{ Normal wood } & \multicolumn{2}{|c|}{ Tension wood } & \multirow[t]{2}{*}{ Band origin, short comments } & \multirow[t]{2}{*}{ References } \\
\hline & CWR & KL & CWR & KL & & \\
\hline 1 & 1738 & -- & 1739 & -- & $\mathrm{C}=\mathrm{O}$ stretching vibration in xylan & Harington et al. (1964) \\
\hline 2 & 1602 & 1619 & 1602 & 1619 & $\begin{array}{l}\text { Aromatic skelton vibration plus } \mathrm{C}=\mathrm{O} \\
\text { stretch; } \mathrm{S}>\mathrm{G} ; \mathrm{G} \text { condensed }>\mathrm{G} \text { etherified }\end{array}$ & Faix (1991) \\
\hline 3 & 1506 & 1499 & 1506 & 1499 & Benzene ring stretching vibration in lignin & Harington et al. (1964) \\
\hline 4 & 1461 & 1460 & 1462 & 1460 & $\begin{array}{l}\mathrm{CH}_{2} \text { deformation vibration in lignin and } \\
\text { Xylan+benzene vibration in lignin }\end{array}$ & Faix (1991), Harington et al. (1964) \\
\hline 5 & 1424 & 1421 & 1425 & 1421 & $\begin{array}{l}\mathrm{CH}_{2} \text { scissor vibration in cellulose }+\mathrm{CH}_{3} \\
\text { bending Vibration in lignin }\end{array}$ & Harington et al. (1964) \\
\hline 6 & 1376 & -- & 1377 & -- & $\begin{array}{l}\mathrm{CH} \text { bending vibration in cellulose and } \\
\text { hemicellulose }\end{array}$ & Faix (1991) \\
\hline 7 & 1328 & -- & 1329 & -- & $\mathrm{C}=\mathrm{O}$ stretching vibration & Faix (1991), Harington et al. (1964) \\
\hline 8 & 1246 & 1221 & 1246 & 1223 & $\mathrm{C}=\mathrm{O}$ stretching vibration in lignin & Harington et al. (1964) \\
\hline 9 & 1160 & -- & 1166 & -- & $\begin{array}{l}\text { C-O-C antisymmetric bridge stretching } \\
\text { vibration in cellulose and hemicellulose }\end{array}$ & Faix (1991), Harington et al. (1964) \\
\hline 10 & 1112 & 1113 & 1112 & 1113 & $\begin{array}{l}\mathrm{OH} \text { association band in cellulose and } \\
\text { hemicellulose }\end{array}$ & Harington et al. (1964) \\
\hline 11 & 1053 & 1053 & 1052 & 1053 & $\begin{array}{l}\mathrm{C}=\mathrm{O} \text { stretching vibration in cellulose and } \\
\text { hemicellulose }\end{array}$ & Harington et al. (1964) \\
\hline
\end{tabular}


and threo isomers of p-hydroxyphenyl $(\mathrm{H})$, guaiacyl $(\mathrm{G})$ and syringyl (S) lignin units (H-CHSEt-CHSEt-CH${ }_{2} \mathrm{SEt}$, G-CHSEt-CHSEt-CH ${ }_{2} \mathrm{SEt}$, S-CHSEt-CHSEt-CH ${ }_{2}$ SEt respectively) as well as G- $\mathrm{CH}_{2}-\mathrm{CHSEt}-\mathrm{CH}(\mathrm{SEt})_{2}$ and $\mathrm{S}-\mathrm{CH}_{2}-$ CHSEt-CH(SEt $)_{2}$. It is apparent from the figure 4 and table 4 that monomeric composition of tension wood lignin was characterized by higher content of p-hydroxyphenyl and syringyl units resulted in higher and $\mathrm{H} / \mathrm{G}$ and $\mathrm{S} / \mathrm{G}$ ratios compared to those of opposite wood (table 4). The relative proportion of $\beta-\mathrm{O}-4$ linkages in $\mathrm{H}, \mathrm{G}$ and $\mathrm{S}$ units determined from the major thioacidolytic products, erythro and threo forms of different monolignol units showed that tension wood of $H$. cannabinus characterized by more $\beta$-aryl ether linkages in $\mathrm{S}$ and $\mathrm{H}$ units (figure 5).

\section{DISCUSSION}

The tension wood of $H$. cannabinus is characterized by the absence of a gelatinous layer. Although G-layer is considered as a typical feature of angiosperm reaction xylem, there are several reports on the occurrence of fibers without G-layers in the wood on upper side of lea-

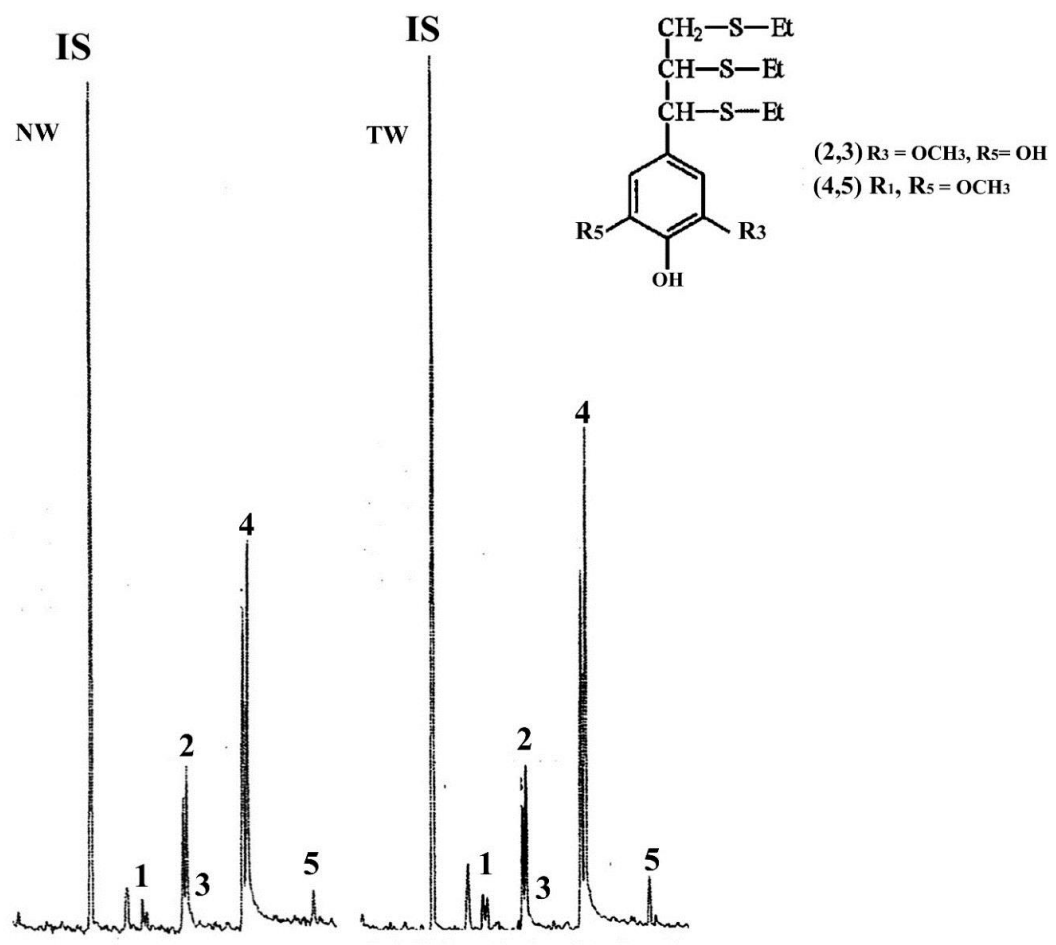

Figure 4. Partial gas chromatographs of TMS thioacidolysis products recovered from normal wood (NW) and tension wood (TW) lignin of $H$. cannabinus.

Cromatografía de gases de los productos de tioacidólisis de TMS recuperados de la lignina de madera normal (NW) y madera en tensión (TW) de H. cannabinus.

Table 4. Monomeric composition of lignin in normal and tension wood of $H$. cannabinus.

Composición monomérica de la lignina en la madera de tensión y la madera normal de H. cannabinus.

\begin{tabular}{lcc}
\hline & Normal wood & Tension wood \\
\hline p-hydroxyphenyl unit $\left(\mu \mathrm{mol} \mathrm{g}^{-1}\right)$ & $70.15 \pm 6$ & $90.35 \pm 3$ \\
Guaiacyl unit $\left(\mu \mathrm{mol} \mathrm{g}^{-1}\right)$ & $310.75 \pm 15$ & $285.35 \pm 12$ \\
Syringyl unit $\left(\mu \mathrm{mol} \mathrm{g}^{-1}\right)$ & $709.17 \pm 16$ & $761.68 \pm 24$ \\
H/G ratio & $0.23 \pm 0.03$ & $0.32 \pm 0.04$ \\
S/G ratio & $2.29 \pm 0.02$ & $2.67 \pm 0.15$ \\
\hline
\end{tabular}




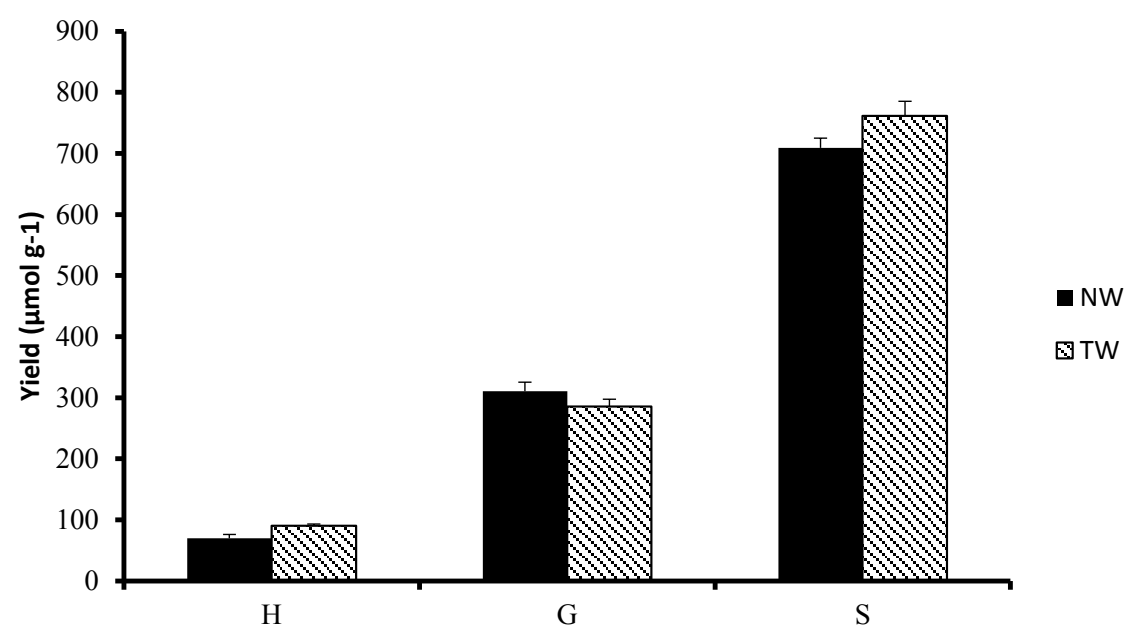

Figure 5. Relative richness of $\beta$-aryl ether linkages in p-hydroxyphenyl $(H)$, guaiacyl $(G)$ and syringyl (S) lignin units. (Calculated from the prominent peaks of erythro/threo forms of each monomeric unit appeared in the gas chromatograph).

Riqueza relativa de enlaces $\beta$-aril éter en unidades de lignina tipo p-hidroxifenil (H), guaiacil (G) y siringil (S). Nota: el cálculo fue hecho a partir de los picos prominentes de las formas eritro/treo en cada unidad monomérica en el cromatógrafo de gases.

ning stem and branches of hard wood species (Bailliers et al. 1996). Clair et al. (2006), reported the absence of Glayer in the tension wood fibers of 14 tropical rain forest species having highly tensile stressed wood. The present study suggests the similar pattern of tension wood formation in the herbaceous plant, $H$. cannabinus, which shows absence of G-fibers on the upper side of the leaning stem. Anatomical studies revealed that the fibers in the $H$. cannabinus TW are shorter and wider compared to those of opposite wood. In case of G-fibers of tree species, vessel elements and fibers are reported to be significantly longer in tension wood compared to opposite wood in poplar (Jourez et al. 2001), while no significant difference in the dimensions of vessels and fibers was noticed in Leucaena leucocephala (Lam) de Wit (Pramod et al. 2013). The fibers without G-layer found in the eccentric growth side of Viburnum oderatissimum (L.) Ker Gawl. were shorter than those found in opposite wood (Wang et al. 2010). These authors suggested that the decrease in fiber length could be due to increasing frequency of anticlinal division during eccentric growth. Therefore, decrease in fiber length and ray height with an increase in their width may be associated with the variation in the frequency of anticlinal/periclinal division in tension and opposite xylem development in $H$. cannabinus. The cell-wall thickness of fibers and vessel elements and vessel density have been found to be decreased in the tension wood of H. cannabinus. In typical tension wood, increased differentiation of G-fibers generally accompanied by a significant decrease of size and density of vessel elements due to the priority for development of elements responsible for mechanical strength (Timel 1986, Pramod et al. 2013). In spite of the lack of G-layers in fibers, the occurrence of typical ten- sion wood associated anatomical features in $H$. cannabinus secondary xylem suggests that G-layer can be considered as one of the characteristics rather than a specific feature of tension wood formation in angiosperms (Clair et al. 2006).

The histochemical analysis of distribution pattern of lignin and syringyl lignin units using Weisner reaction and Maule's test suggests relatively high syringyl lignin units in the tension wood fibers of $H$. cannabinus. In typical tension wood fibers with gelatinous layers, reports on distribution pattern of syringyl units are controversial within different species. More syringyl units are reported in the G-fibers of Populous deltoids (Joseleau et al. 2004), while more amount of guaiacyl units were noticed in the G-fibers of Leucaena leucocephala (Pramod et al. 2013). On the other hand, Magnolia species showed no difference in the distribution of lignin monomers between tension and opposite wood (Yoshizawa et al. 2000). In herbaceous plants, Liriodendron tulifera L., less syringyl units have been reported in tension wood fibers (Jin and Kwon 2009). The unusual reaction xylem in the Viburnum odoratissimum characterized by eccentric growth on the lower side of branches (region opposite to larger growth stress) showed fibers without G-layer although possessing less syringyl lignin units (Wang et al. 2010). The reaction xylem fibers without G-layer in H. cannabinus xylem, on the contrary, showed an increase in syringyl lignin distribution on the region of eccentric growth.

The FTIR analysis has revealed the presence of prominent peaks in the fingerprint region (1800-600 $\left.\mathrm{cm}^{-1}\right)$ reported to be specific to cellulose, hemicelluloses and lignin (Faix 1991). IR spectra of Klason lignin show that peaks corresponding to lignins have shifted to new posi- 
tions from those found in CWR. According to Rana et al. (2009), this kind of peak shift in FTIR spectra might be caused by inductive effects of substituents $\left(e . g ., \mathrm{H}_{3} \mathrm{CO}_{3}\right)$ in the aromatic ring system of lignin.

The relative proportion of monolignol units $(\mathrm{H}, \mathrm{G}$ and S) is believed to be an important feature determining the biological origin of lignin, physical and mechanical characteristics of xylem. In the present study, results of the thioacidolysis analysis showed higher proportion of syringyl lignin units compared to $\mathrm{H}$ and $\mathrm{G}$ units in the H. cannabinus xylem. A previous study on isolated lignin from bast fibers (Ralph 1996) and core xylem (Jin et al. 2012) of $H$. cannabinus reported it to contain a high syringyl: guaiacyl ratio, and to have high $\beta$-aryl ether units with predominantly erythro form as the predominant form of aryl $\beta$-ether intermonomer linkage in the stereo chemistry of lignin. On the contrary, determination of lignin monomeric composition using the permanganate oxidation method showed higher content of $\mathrm{H}$ and $\mathrm{G}$ units while relatively low $\mathrm{S}$ units in the core xylem of $H$. cannabinus grown in Portugal (Neto et al. 1996). The selective degradation of aliphatic side chains attached to aromatic moieties in lignin during permanganate oxidation can be useful to analyze only a small fraction of lignin structure (Gellerstedt 1992). Thioacidolysis is specific for degradation of aryl $\beta$-ether linkages, which form the most abundant binding form in lignin polymer (Nishimura et al. 2002). Therefore, the degradation mechanism of methods and samples employed could probably be responsible for the variation in H:G:S ratio of $H$. cannabinus lignin. The efficient and specific cleavage of $\beta$-aryl ether linkages of $H$. cannabinus lignin by thioacidolysis was evident from the observed prominent peaks $(3,5)$ in the chromatograph (figure 4) corresponds to the amount of uncondensed alkyl aryl ether linkages in guaiacyl and syringyl lignin units. Therefore, the $\mathrm{S} / \mathrm{G}$ ratio calculated from these peaks reflects the proportion of $\beta$-aryl ether subunits in $\mathrm{S}$ and $\mathrm{G}$ lignin units. The high $\mathrm{S} / \mathrm{G}$ ratio in $H$. cannabinus tension wood suggests more amount of $\beta$-aryl ether linkages in syringyl lignin units compared to that of opposite wood.

The major difference found in the lignin monomeric composition of $H$. cannabinus tension wood was an increase in $\mathrm{H}$ and $\mathrm{S}$ monomers compared to those of opposite wood. Previous studies on characterization of lignin in the tension wood of different dicots have showed a high heterogeneity between different species. In poplar, thioacidolysis data showed an $\mathrm{S} / \mathrm{G}$ ratio lower than that of opposite wood (Lapierre and Monties 1986). The branches of Viburnum odoratissimum also showed an $\mathrm{S} / \mathrm{G}$ ratio in the eccentric growth side lower than that shown by opposite growth side (Wang et al. 2010). These authors suggested that the altered proportion of $\mathrm{S} / \mathrm{G}$ ratio and $\beta-\mathrm{O}-4$ linkages in the lower side of branches provides high rigidity and lower viscosity to sustain downward bending due to gravitational force. Rodrigues et al. (2001), reported that tension wood of Eucalyptus globulus has no significant variation in $\mathrm{S} / \mathrm{G}$ ratio as compared to opposite wood. On the contrary, Aguayo et al. (2010), noticed a high syringyl lignin content in the tension wood of Eucalyptus sp. Our results also suggested higher syringyl lignin content in the tension wood of $H$. cannabinus. It is also noteworthy a relatively higher content of p-hydroxyphenyl $(\mathrm{H})$ units in H. cannabinus tension wood compared to that of opposite wood. Compression wood in gymnosperms reported to have more $\mathrm{H}$-units than those found in normal wood (Timel 1986, Bailers et al. 1996). According to Bailleres et al. (1996), the proportion of $\mathrm{H}$ units increased significantly during transition from normal to compression wood in Buxus sempervirens L. The increase in $\mathrm{H}$ units of $H$. cannabinus tension wood suggests a chemical resemblance in the variation pattern of monomeric composition to that of compression wood. The rigidity and strength properties are mainly attributed to a condensed form of $\mathrm{G}$ and $\mathrm{H}$ units, which form more carbon-carbon linkages compared to $\mathrm{S}$ units rich in $\beta-\mathrm{O}-4$ linkages (Boerjan et al. 2003). Hence, increase in $\mathrm{H}$ lignin units in H. cannabinus tension wood may be an alternative mechanism to balance the rigidity and strength properties. Further, from the industrial perspective, the presence of longer xylem fibers, higher cellulose content and the increase in $\mathrm{S} / \mathrm{G}$ ratio in tension wood is a desirable feature for textile fibers or processing of lignocellulose biomass for paper and pulp or bioenergy applications.

\section{CONCLUSIONS}

The present study demonstrated that the tension wood (upper side of the bending stem) of $H$. cannabinus is a variant due to the absence of G-layer in fibers. However, it shows several typical tension wood anatomical features such as decrease in vessel density, thickness of fiber wall, density and height of xylem rays etc. The histochemical analysis revealed a higher distribution of syringyl lignin units in the tension wood fiber wall. Although, there is no difference in the amount of lignin between tension wood and opposite wood, TW lignin was also characterized by the presence of more syringyl and p-hydroxyphenyl units in its monomeric composition. The thioacidolysis analysis also suggested TW lignin is rich in $\beta$-aryl ether linked syringyl units resulting an $\mathrm{S} / \mathrm{G}$ ratio higher than that of opposite wood.

\section{ACKNOWLEDGEMENTS}

The present work is part of a work done under Dr. D.S. Kothari post-doctoral fellowship (to Pramod S.) awarded by University Grants Commission, Government of India. The first author is thankful to University Grants Commission, New Delhi for Providing financial assistance under UGC-DSKPDF scheme. Authors are grateful to both anonymous reviewers for their valuable suggestions on the earlier version. 


\section{REFERENCES}

Aguayo MG, L Quintupill, R Castillo, J Baeza, J Freer, RT Mendonça. 2010. Determination of differences in anatomical and chemical characteristics of tension and opposite wood of 8-year-old Eucalyptus globulus. Maderas. Ciencia y Tecnología 12(3): 241-252.

Almeras T, B Clair. 2016. Critical review on the mechanism of maturation stress generation in trees. Journal of the Royal Society Interface 13: 20160550. DOI: https://doi. org/10.1098/rsif.2016.0550

Baba K, T Ona, K Takabe, T Itoh, K Ito 1996. Chemical and anatomical characterization of the tension wood of Eucalyptus camaldulensis L. Mokuzai Gakkaishi 42: 795-798

Bailleres H, M Castin, B Monties, B Pollet, C Lapierre. 1996. Lignin structure in Buxus sempervirens reaction wood. Phytochemistry 44: 35-39. DOI: https://doi.org/10.1016/ $\underline{\mathrm{S} 0031-9422(96) 00499-2}$

Berlyn GP, JP Mikshe. 1976. Botanical microtechnique and cytochemistry. Ames, Iowa, USA. Iowa State University Press. $326 \mathrm{p}$.

Boerjan W, J Ralph, M Baucher. 2003. Lignin biosynthesis. Annual Review of Plant Biology 54: 519-546. DOI: https:// doi.org/10.1146/annurev.arplant.54.031902.134938

Clair B, J Ruelle, J Beauchene, M-F Prevost, M Fournier. 2006. Tension wood and opposite wood in 21 tropical rain forest species. 1. Occurrence and efficiency of G-layer. International Association of Wood Anatomists Journal 27: 329338. DOI: http://doi.org/10.1163/22941932-90000158

Clair B, J. Alteyrac, A Gronvold, J Espejo, B Chanson, T. Alméras. 2013. Patterns of longitudinal and tangential maturation stresses in Eucalyptus nitens plantation trees. Annals of Forest Science 70: 801-811. DOI: http://doi.org/10.1007/ s13595-013-0318-4

Cunningham RL, ME Carr, MO Bagby. 1986. Hemicellulose isolation from annual plants. Biotechnology and Bioengineering Symposium 17: 159-168.

Dence CW. 1992. The determination of Lignin. In Lin SY, CW Dence eds. Methods in lignin chemistry. Springer-Verlag. p 33-61.

Faix O. 1991. Classification of lignin from different botanical origin by FTIR spectroscopy. Holzforschung 45: 21-27. DOI: https://doi.org/10.1515/hfsg.1991.45.s1.21

Gellerstedt G. 1992. Permanganate oxidation. In Lin SY, CW Dence eds. Methods in lignin chemistry. Springer-Verlag. p. 322-332.

Groover A. 2016. Gravitropism and reaction wood of forest treesevolution, function and mechanism. New Phytologists 211: 790-802. DOI: https://doi.org/10.1111/nph.13968

Jin H, M Kwon. 2009. Mechanical bending-induced tension wood formation with reduced lignin biosynthesis in Liriodendron tulipifera. Journal of Wood Science 55: 401-408. DOI: https://doi.org/10.1007/s10086-009-1053-1

Jin Z, G Jin, S Shao, KS Katsumata. 2012. Lignin characteristics of bast fibre and ore in kenaf, bark and wood of paper mulberry and mulberry. Journal of Wood Science 58: 144-152. DOI: https://doi.org/10.1007/s10086-011-1228-4

Joseleau JP, T Imai, K Kuroda, K Ruel. 2004. Detection in situ and characterization of lignin in the G-layer of tension wood fibres of Populus deltoids. Planta 219: 338-345. DOI: https://doi.org/10.1007/s00425-004-1226-5
Jourez B, A Riboux, A Leclercq. 2001. Anatomical characteristics of tension wood and opposite wood in young inclined stem of Poplar (Populus euramericana cv 'Ghjoy'). International Association of Wood anatomists Journal 22: $133-157$

Lapierre C, B Monties. 1986. Thioacidolysis of poplar lignins: identification of monomeric syringyl products and characterization of Guaiacyl-Syringyl lignin fractions. Holzforschung 40: 113-118. DOI: http://doi.org/10.1515/ hfsg.1986.40.2.113

Lapierre C, B Pollet, C Ronaldo. 1995. New insights into the molecular architecture of hard wood lignins by chemical degradative methods. Research on Chemical Intermediates 21: 397-412. DOI: https://doi.org/10.1007/BF03052266

Mehistsuka G, J Nakano. 1979. Studies on the mechanism of lignin colour reaction (XIII): Maüle colour reaction (9). $\mathrm{Mo}$ kuzai Gakkaishi 25: 588-594. DOI: https://doi.org/10.1016/ $\underline{\text { S0926-6690(01)00101-7 }}$

Neto C, A Seca, D Fradinho, MA Coimbra, F Domingues, D Evtuguin, A Silvestre, JAS Cavaleiro. 1996. Chemical composition and structural features of macromolecular components of Hibiscus cannabinus grown in Portugal. Industrial Crops and Products 5: 189-196. DOI: https://doi. org/10.1016/0926-6690(96)89448-9

Nishimura N, A Izumi, K-I Kuroda. 2002. Structural characterization of kenaf lignin: differences among kenaf verities. Industrial Crops and Products 15: 115-122.

Pramod S, KS Rao, A Sundberg. 2013. Structural, histochemical and chemical characterization of normal, tension and opposite wood of Subabul (Leucaena leucocephala). Wood Science and Technology 47: 777-796. DOI: https://doi. org/10.1007/s00226-013-0528-9

Pramod S, KS Rajput, KS Rao. 2019. Immunolocalization of $\beta$ (1-4) D-galactan, xyloglucans and xylans in the reaction xylem fibres of Leucaena leucocephala (Lam.) de Wit. Plant Physiology and Biochemistry 142: 217-223. DOI: 10.1016/j.plaphy.2019.07.013

Ralph J. 1996. An unusual lignin from kenaf. Journal of Natural Products 59: 341-342. DOI: https://doi.org/10.1021/ $\underline{\mathrm{np} 960143 \mathrm{~s}}$

Ramage MH, H Burridge, M Busse-Wicher, Feredey G, T Reynolds, DU Shah, G Wu, L Yu, P Fleming, DD Tingley, J Allwood, P Dupree, PF Linden, O Scherman. 2017. The wood from the trees: The use of timber in construction. Renewable and Sustainable Energy Reviews 68: 333-359. DOI: https://doi.org/10.1016/j.rser.2016.09.107

Rana R, RL Heyser, R Finkeldey, A Polle. 2009. FTIR spectroscopy, chemical and histochemical characterization of wood and lignin of five tropical timber wood species of the family Dipterocarpaceae. Wood Science and Technology 44(2): 225-242. DOI: https://doi.org/10.1007/s00226-009-0281-2

Rodrigues J, J Graca, H Pereira. 2001. Influence of tree eccentric growth on syringyl/guaiacyl ratio in Eucalyptus globulus wood lignin assessed by analytical pyrolysis. Journal of Analytical and Applied Pyrolysis 58: 481-489. DOI: https://doi.org/10.1016/S0165-2370(00)00121-2

Rolando, C, B Monties, C Lapierre. 1992. Thioacidolysis. In Lin S, C Dence eds. Methods in Lignin Chemistry. Berlin, Germany. Springer-Verlag. p. 334-349.

Saikia CN, NN Dutta, M Borah. 1993. Thermal behaviour of some homogeneously esterified products of high a-cellulo- 
se pulps of fast-growing plant species. Thermochimica Acta 219(1-2): 191-203. DOI: https://doi.org/10.1016/00406031(93)80497-X

Sellers T, GD Miller, MJ Fuller. 1993. Kenaf core as a board raw material. Forest Products Journal 43: 69-71.

Srebotnik E, K Messener. 1994. A simple method that uses differential staining and light microscopy to assess the selectivity of wood delignification by white rot fungi. Applied and Environmental Microbiology 60: 1383-1386.

Timel TE. 1986. Compression wood in Gymnosperms. Vol. I. Springer, Berlin.

Vallet C, B Chabbert, Y Czaninski, B Monties. 1996. Histochemistry of lignin deposition during sclerenchyma differentiation in alfalfa stems. Annals of Botany 78: 625-632. DOI: https://doi.org/10.1006/anbo.1996.0170

Wang Y, J Grill, B Clair, K Minato, J Sugiyama. 2010. Wood properties and chemical composition of the eccentric growth branch of Viburnum odoratissimum var. awabuki. Trees: Structure and Function 24(3): 541-549. DOI: http://doi. org/10.1007/s00468-010-0425-x

Yokoyama T, JF Kadla, H-M Chang. 2002. Microanalytical method for the characterization of fibre components and morphology of woody plants. Journal of Agricultural and Food Chemistry 50: 1040-1044. DOI: http://doi. org/10.1021/jf011173q

Yoshida M, T Okuda, T. Okuyama. 2000. Tension wood and growth stress induced by artificial inclination in Liriodendron tulifera Linn. and Prunus spachiana Kitamura f. ascendens Kitamura. Annals of Forest Science 57: 739-746. DOI: https://doi.org/10.1051/forest:2000156

Yoshizawa N, A Inami, S Miyake, F Ishiguri, S Yokota. 2000. Anatomy and lignin distribution of reaction wood in two Magnolia species. Wood Science and Technology 34: 183196. DOI: http://doi.org/10.1007/s002260000046

Recibido: 02/10/20

Aceptado: 28/12/20 